\title{
Mexico's Automotive Industry: A Success Story?
}

\author{
Jorge Carreto Sanginés, Margherita Russo, \\ Annamaria Simonazzi *
}

Working Paper No. 166

October $5^{\text {th }}, 2021$

\begin{abstract}
In less than three decades Mexico's automotive industry has gone from a minor role to the $7^{\text {th }}$ largest world producer of automotive vehicles. The Mexican experience is part of the more general case of the "integrated peripheries." The development of these cannot be accounted for separately from the developments occurring in its core country. Unlike the core-periphery literature, however, our analysis emphasizes that the various clusters of cores and integrated peripheries are not alike. In the case under study, the core has been systematically lagging behind the main transformations pioneered by its competitors.

The paper traces the evolution of the Mexican automotive industry, emphasizing the difficulties faced by a late-comer country in developing an independent industry, and the importance of policy choices as well as the macroeconomic context in affecting its development. NAFTA

\footnotetext{
* Facultad de Economía, Universidad Nacional Autónoma de México, Mexico, jcarreto@economia.unam.mx; Department of Economics, University of Modena and Reggio Emilia, Modena, Italy, and CAPP Research Centre for the Analysis of Public Policies, Modena, Italy margherita.russo@unimore.it; Former Professor of Economics, Dipartimento di Economia e Diritto, Sapienza Università di Roma, Italy, annamaria.simonazzi@uniroma1.it, corresponding author. This paper is part of the research project "Geopolitical and technological challenges for the automotive global value chains", PI Annamaria Simonazzi, funded by INET. The analysis on Mexico has been developed under the complementary project "Digital transformation in the automotive supply chain in Mexico", PI Jorge Carreto Sanginés, funded by UNAM PAPIIT IN309620.
} 
represents the culmination of an integration process that has profoundly transformed the structure of the Mexican automotive industry, deepening its dependence on the US market. While there is no doubt that it has contributed to the spectacular growth of the Mexican auto industry, whether it also increased its resilience or, rather, its dependence is still an open question. This issue is particularly relevant in view of the transformations that are taking place in the automotive sector and in the geopolitical scenario. These include the end of NAFTA and the advent of USMCA, the entry of powerful competitors into the global market, and the transition to electric and autonomous vehicles, which all entail risks and opportunities. The lens of the centre-periphery relationship can help to understand the present integration of North America and its future direction.

https://doi.org/10.36687/inetwp166

JEL codes: L62; F23; O3.

Keywords: automotive industry; Mexico; global production networks; core-periphery 


\section{Introduction}

In less than three decades the Mexican automotive industry has gone from a minor role to the $7^{\text {th }}$ largest world producer of automotive vehicles. This spectacular growth occurred in symbiosis with the evolution of the US economy and policy. After an initial period of import substitution, the Mexican automotive industry developed first as a cheap producer of parts and components for the three US automakers, to grow then as an integral part of the North American productive system, as well as the necessary entry point to the American market for non-American automotive companies.

The Mexican experience is part of the more general case of the "integrated peripheries". Analysis of it can help cast some light on the prospects of these economies in the new division of labor ushered in by technological, consumption, and geo-political changes. As in the general case of "integrated peripheries", its development cannot be accounted for separately from the developments occurring in its core country. Unlike the core-periphery literature, however, our analysis emphasizes that the various clusters of cores and integrated peripheries are not alike. In the case under study, the core has been systematically lagging behind the main transformations pioneered by its competitors. In the 1970s-80s, US companies had to respond to the increasing foreign (mainly Japanese) competition in their own, hitherto protected, market. It is in this context that, among the various strategies adopted, offshoring of labor-intensive operations and delocalization of assembly plants to Mexico took on increasing importance. In the current transition, once again the US has been lagging behind in the electric vehicles revolution, only recently making an effort to catch up with China and the EU, and the potential of Mexico is on the move.

The second aim of the paper is to consider the difficulties faced by a late-comer country in developing an independent industry. Hirschman referred to the existence of "constellations of productive forces' that can drive towards success, but can also open the way to 'particularly unfortunate combinations of circumstances' which lead to lack of development (Ginzburg and Simonazzi, 2005). In our analysis, we shall emphasize the importance of policy choices as well as the macroeconomic context in affecting the expansion of the domestic market, and, in turn, the development of an independent automotive industry. 
The paper traces the evolution of the Mexican automotive industry from the demise of the import substitution policy (ISI, Import Substitution Industrialization), through the two treaties with its North-American partners (NAFTA in 1994, replaced by the USMCA in 2020). NAFTA represents the culmination of an integration process that has profoundly transformed the structure of the Mexican automotive industry, deepening its dependence on the US market. Indeed, despite the many free trade agreements signed by Mexico with other countries and regional organizations, after 25 years of NAFTA more than $80 \%$ of Mexican exports are still concentrated in the US. While there is no doubt that NAFTA has contributed to the spectacular growth of the Mexican auto industry, whether it also increased its resilience or, rather, its dependence is still an open question. This issue is particularly relevant in view of the transformations that are taking place in the automotive sector and in the geopolitical scenario: the end of NAFTA and the advent of USMCA, the entry of powerful competitors into the global market, the transition to electric and autonomous vehicles entail risks and opportunities. The lens of the centre-periphery relationship can help to understand the present integration of North America and its future direction.

The paper is structured as follows. Section 2 outlines the main facts and figures characterizing the Mexican economy before NAFTA and Section 3 describes NAFTA. Section 4 places NAFTA in the overall framework of trade agreements and the regionalization of the automotive world production. Section 5 discusses the actual impact on labor cost differentials in Mexico and the US compared with expectations raised by the elimination of tariffs in regional trade and with the USMCA requirements. Section 6 concludes with the two main goals of our analysis, focusing on the dynamic hierarchical division of labor in which Mexico is now placed and on the paths for the Mexican automotive industry to catch up in a multilateral trade world.

\section{The road to NAFTA}

\subsection{From ISI to export orientation in Mexico: push and pull factors}

The effort to industrialize the country through import-substitution policies dates back to the prewar period and gained momentum in the 1960s and 1970s, when the Mexican government attempted to control foreign investment through two main strategies: nationalization and "Mexicanization" (Benneth and Sharpe 1981). Protection characterized industrial policy until the 
1970s and has been gradually dismantled since the 1980s. Since the liberalization of the economy, industrial policy essentially consisted in controlling wages and reducing risks for investors in order to attract FDI.

Development of a domestic automotive industry had been a specific objective of industrial policy since the 1930s, when the Detroit 3 (GM, Ford, and Chrysler) set up assembly plants in Mexico City $^{1}$, and it was implemented through various Decrees. After thirty years, import banning gave further boost in that direction. The 1962 "Integration Decree" prohibited imports of finished vehicles and imposed high local-content requirements on assembly carried out in Mexico. Following the Decree, vehicle manufacturers were forced to move from being simply assemblers (with less than 20 per cent of national origin components) to making vehicles, engines, parts, and components locally. The protectionist set of decrees was complemented in 1973 with the Foreign Investment Law (Ley de Inversiones Extranjeras) which limited to 40 per cent the share of foreign investment in companies producing parts for automotive vehicles. In 1977, a new automotive decree prioritized exports over import substitution for finished products, requiring assemblers to balance exports and imports of inputs and comply with the $60 \%$ regional value content.

Despite the various attempts at encouraging the domestic production of components, the national integration of the supply chain (the "mexicanización" of industry) failed. The market for motor vehicles in Mexico was too small, and the number of models assembled in Mexico too high to achieve scale economies, thus making production unprofitable. Eleven of the nineteen assembly plants closed down (Brincks et al. 2018), and five of the six automakers active in Mexico in 1965 (the so-called "legacy" producers) ${ }^{2}$ would remain the only automakers producing in Mexico until 1995.

1 In 1925, Ford Motor Company opened a new company in Mexico City and in 1930 built its first assembly plant in the country. The Mexican government offered Ford, among other advantages, a 50\% discount on import duties on inputs, rail freight tariff concessions and a very significant promise: no problems with labor unions. The other two big sisters: General Motors Corporation (G.M.) and Chrysler, followed suit a few years later: G.M. started manufacturing trucks in 1937 and assembling automobiles the following year; Chrysler installed its first assembly plant in 1938. At the same time, they also installed factories to produce auto parts (Castellanos, 2016).

2 The OEMs present in Mexico in 1965 were: Chrysler, Ford Motor, General Motors, Volkswagen de México, Nissan Mexicana, Vehículos Automotores Mexicanos (60\% Mexican Government, 40\% American Motors) (Solís, 2009). Other companies built their factories to produce trucks and heavy vehicles, among them Fábricas Autocar Mexicana, Kenworth and International Harvester. 
With the establishment, in 1965, of the maquiladora program, the Mexican government integrated the protection of the domestic market with a more export-oriented policy. The program allowed foreign-owned businesses to set up assembly plants in Mexico for re-export as part of the Border Industrialization Program. As explained in the following section, only a decade later the US automotive companies began to take advantage of it. But the overall result was that output in the automotive industry remained below capacity, costs and prices remained high, and imports of capital and intermediate goods fed a trade deficit.

In 1978, the discovery of enormous oil reserves opened a decade characterized by the oil boombust and recurrent financial crises. The oil boom prompted plans to transform Mexico into a highly competitive exporting country: public expenditure and debt grew accordingly. A relatively small domestic market, high dependence on imported inputs and technology, and an overvalued currency contributed to the country's growing indebtedness, made possible by the necessity of international banks to lend the flood of liquidity resulting from the petrodollar market (Simonazzi 1984; Ros Bosch 2013; Romero and Berasaluce 2018). The oil price collapse and Volcker's U-turn in monetary policy put an end to the "management of affluence" rhetoric of president López Portillo (1976-1982) as well as any ambition for an industrial policy.

Multilateral agencies and the U.S. Treasury made debt restructuring conditional on opening the country to FDI and foreign competition, implementing market-oriented reforms, cutting government expenditure and budget deficits. With foreign debt destabilizing the exchange rate, inflation approaching triple-digit levels and capital flight fueling balance of payments and currency crises, the government had no choice but to comply. In December 1982, the IMF and the Mexican government signed the "Acuerdo de facilidad ampliada" (Expanded Facility Agreement), which mandated the classical Washington Consensus adjustment measures. In the same month, the government implemented the "Programa Inmediato de Reordenación Económica" (Immediate Economic Reorganization Program), which lowered the average tariffs on imports and marked the beginning of the dismantling of the import-substitution policy. In the space of five years after the 1982 crisis, real wages fell by $42 \%$, incomes and imports diminished, and the trade balance moved to surplus.

The policy change continued in 1983, with the Automotive decree ("Decreto para el fomento $y$ modernización de la industria automotriz") which allowed carmakers to gradually reduce the 
number of models produced at their Mexican assembly plants from 3 to 2, down to 1 by 1987 . Local content requirements for finished vehicles increased, but imports were allowed if balanced by exports. A new government decree in 1989 reduced domestic content requirements and lightened import restrictions, allowing imports of new cars to complement the local production.

Liberalization, deregulation and free-market "revolution" in Mexico, driven by international financial pressures, were propitiated by the ascent in Mexico of a generation of foreign-educated technocrats who embraced neo-liberal ideas. The demise of the ISI strategy gave way to an openmarket approach that assigned greater weight to the market in allocating resources, encouraged foreign direct investment and allowed 100\% foreign ownership of plants. The new rules simplified administrative procedures, deregulated the financial sector and reformed the tax system, reducing income tax rates for companies and individuals (BdeM, 1990). To secure the new regime - in particular, trade liberalization and the phasing out of tariffs and trade barriers in July 1986 Mexico joined the General Agreement on Tariffs and Trade (GATT).

The devaluation of the peso and the austerity policies following the 1982 and 1986 crises killed the domestic market, but automotive production grew rapidly on the expectation of exporting cheap cars to the North American market (Womack, Jones, and Roos 1990). Between 1982 and 1993, the production of motor vehicles grew at an average compound rate of $13.4 \%$ (Table 1). By the time NAFTA was signed in 1993, it had reached 1.06 million vehicles (up from 285 thousand in 1983), Figure $1 .{ }^{3}$ Its share of the manufacturing value-added rose from 4\% in 1970 to $12 \%$ in 1991 and $15 \%$ in 1997 (INEGI, 1980, 2000).

3 Between 1983 and 1993, production of cars rose from 207 thousand to 835 thousand and production of trucks from 78 thousand to 220 thousand; this was before NAFTA. During the NAFTA period, production of cars went from 856.6 thousand in 1994 to 1.4 million in 2019 and that of trucks, from 241 thousand, to 2.6 million (Figure 1). Based on the Corporate Average Fuel Economy (CAFE) and greenhouse gas (GHG) regulatory definitions, all two-wheel drive SUVs under 6,000 pounds GVW are classified as cars, while most SUVs that have four-wheel drive or are above 6,000 pounds GVW are considered trucks. SUV models that are less than 6,000 pounds GVW can have both car and truck variants, with two-wheel drive versions classified as cars and four-wheel drive versions classified as trucks. 
Table 1. Compound Average Rate of Growth (CAGR) of motor vehicle production : Number of vehicles

\begin{tabular}{|c|c|c|c|}
\cline { 2 - 4 } \multicolumn{1}{c|}{} & TOTAL & automobiles & buses \& trucks \\
\hline CAGR 1950-1982 & 9.0 & 9.8 & 8.0 \\
\hline CAGR 1982-1993 & 13.4 & 13.7 & 12.8 \\
\hline CAGR 1993-2004 & 4.3 & 4.5 & 4.1 \\
\hline CAGR 2004-2019 & 6.5 & 2.9 & 9.6 \\
\hline
\end{tabular}

Source: author's elaboration on data from www.inegi.org

Figure 1 - Production of motor vehicles in Mexico. 1983-2020

Columns: total production; thick line: trucks \& buses; dotted line: cars. Units of vehicles

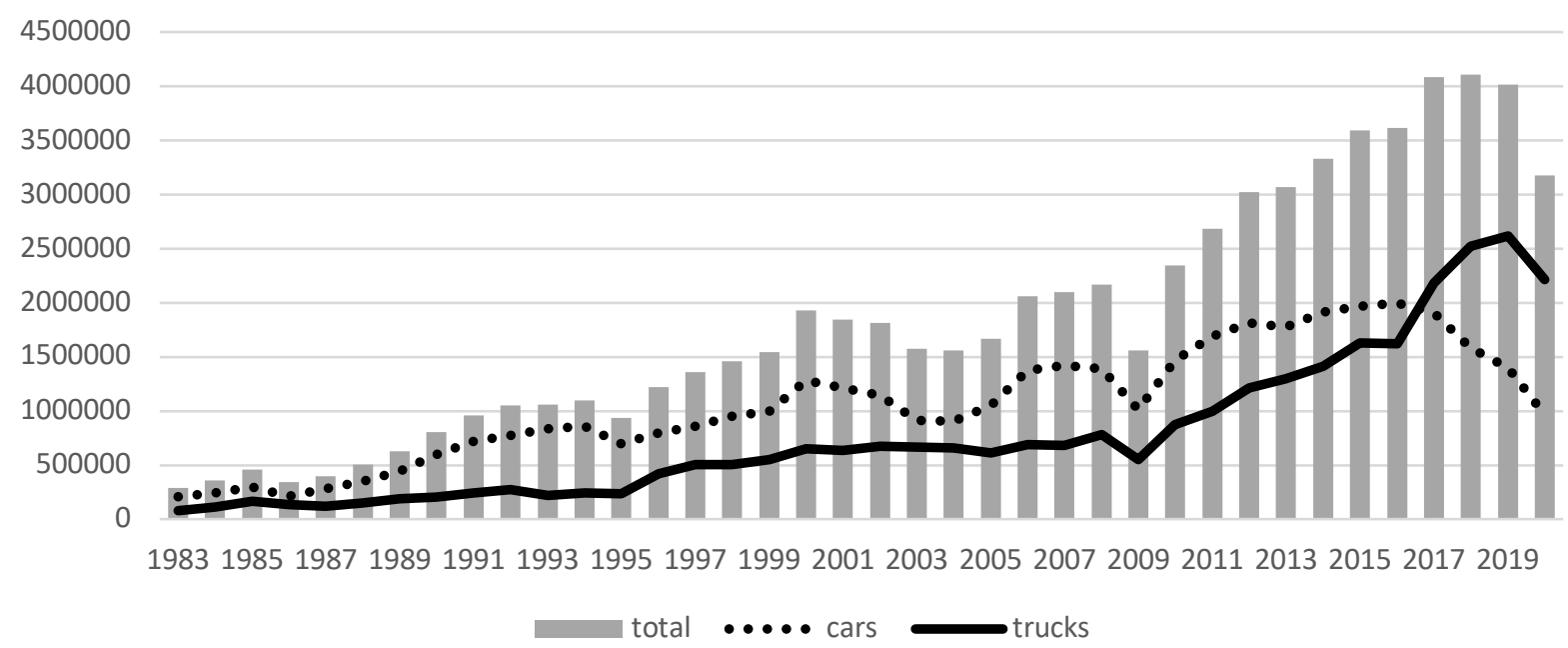

Source: INEGI; https://www.inegi.org.mx/sistemas/bie/\#D10900540

\subsection{Meanwhile in the US: the bumpy road from mass-production towards lean production}

Up until the 1960s, in the US an oligopolistic regime worked quite effectively in ensuring high profits and cozy labor relations. Under the leadership of GM, the Detroit 3 shared the market, none going too close to 50 per cent for fear of the antitrust legislation. They enjoyed high barriers to entry - OEMs made their own engines, transmissions and parts, and managed their own dealership networks - but were exposed to entry "from below" - nearly all of the early imports were small cars from Europe ${ }^{4}$. In 1960, imports from outside North America accounted for 7 per cent of total sales in the domestic market. The share rose to 13 per cent in 1970 and

4 In the early 1970s, European carmakers accounted for 64 percent of US imports, with Renault leading in 1959, and VW between 1960 and 1974 (Klier and Rubenstein 2020, p. 57). 
almost doubled between 1976 and 1980, soaring from $14.8 \%$ to $26.5 \%$ in just four years. Behind this spectacular performance stood Japan, which displaced Europe: in the same four years, its share of the US market soared from 9.3 to 21.1 percent, and in 1980 it accounted for 77 per cent of US imports (it was 85 per cent in 1990) (Klier and Rubenstein, 2020, p. 57-58).

The two oil shocks (1973 and especially 1979) redirected demand toward smaller cars. Demand for compact cars soared. Japanese cars were more fuel-efficient and reliable, and their production costs were about $25 \%$ below the US cost for a similar car. Quality, reliability, cost: Japan's triumph and Detroit's humiliation seemed to confirm America's industrial decline. In the 1970s, the manufacturing belt lost about 1 million manufacturing jobs (Norton 1986; Secrest 1981).

The 1981 U-turn in monetary policy and the deregulation wave, inaugurated in the Carter-Ford era and energetically pursued by Reagan, changed the context. Domestic firms responded to the Japanese assault in various ways: lobbying for protection, adopting labor cost-cutting measures, and, finally, imitating the Japanese just-in-time (JIT) and lean-production techniques, combining managerial and process innovations, also through joint-ventures with Japanese companies. The voluntary export restraint, negotiated with the Japanese government, put an end to the growth of imports of finished vehicles, opening the way to the Japanese "transplants". Between 1982 and 1987, all the leading Japanese carmakers had established plants in the US (Table 2). By 1990 the share of Japanese imports in the US market had declined to 22 per cent. 
Table 2 North American Passenger Car Assembly Plants, 1992

\begin{tabular}{|c|c|c|c|c|c|}
\hline & & United States & Canada & Mexico & Total \\
\hline \multirow{3}{*}{ Detroit 3} & General Motors & 16 & 2 & 1 & 19 \\
\hline & Ford & 7 & 2 & 2 & 11 \\
\hline & Chrysler & 4 & 1 & 1 & 6 \\
\hline \multirow{7}{*}{$\begin{array}{l}\text { Wholly owned } \\
\text { transplants }\end{array}$} & Honda (1982) & 2 & 1 & & 3 \\
\hline & Nissan (1983) & 1 & & 1 & 2 \\
\hline & Toyota (1984) & 1 & 1 & & 2 \\
\hline & Hyundai & & 1 & & 1 \\
\hline & Mitsubishi (a) (1987) & 1 & & & 1 \\
\hline & Volkswagen & & & 1 & 1 \\
\hline & Volvo & & 1 & & 1 \\
\hline \multirow{5}{*}{$\begin{array}{l}\text { Joint-Venture } \\
\text { Transplants }\end{array}$} & CAMI (GM-Suzuki) & & 1 & & 1 \\
\hline & Mazda (b) (1987) & 1 & & & 1 \\
\hline & NUMMI (GM-Toyota) (c) & 1 & & & 1 \\
\hline & Subaru-Isuzu (1989) & 1 & & & 1 \\
\hline & Total & 35 & 10 & 6 & 51 \\
\hline
\end{tabular}

Source: U.S. Congress, Office of Technology Assessment (1992). (a) joint venture with Chrysler dissolved in October 1991; (b) Ford purchased 50\% share in 1992; (c) Dissolved in 1996

In the first years of Japanese imports penetration, Detroit's executives had blamed the workers for poor quality and expected the Japanese transplants to face the same problems. OEMs negotiated major wage concessions and looser restrictive rules from the unions, or moved south to "right to work" states, or further south, to Mexico. For labor-intensive items, such as wire harnessing, GM and the others turned to the maquiladora operations. When, finally, the influential research funded by the MIT International Motor Vehicle Project (Womack, Jones, and Roos 1990) convinced top executives in the US (and Europe) that change was needed, Fordist mass production methods were superseded by "lean production"(Smitka and Warrian, 2016, ch. 10). However, it took time for the new organization of production to set in, and specifically for the long-term, close relationship between automakers and their suppliers to be secured (Helper 1994).

U.S. parts suppliers bore the brunt of the increasing competition from Japanese imports, directly and indirectly. First of all, the US did not have minimum domestic content rules and foreign 
firms bought only simple, low-valued-added parts - such as gaskets and hoses - from independent US suppliers. Later on, as Japanese suppliers of parts and components followed their keiretsu to the US - in 1992 there were about 300 plants in the US and Canada - the new, more efficient plants put pressure on older facilities owned by US firms, who saw their market share decline, as their traditional customers - the Detroit 3 - lost sales to Japanese automakers. Moreover, Japanese suppliers at home and their transplant suppliers in the United States benefited from the new lean production techniques. When the US automakers adopted the justin-time (JIT) organization of production, their suppliers were often forced to adopt "JIT delivery without JIT production", that is, as a supplier put it, "JIT only transfers inventory responsibility from customers to suppliers", with all the associated inventory costs (Helper and Sako 1995, 84; Harrison 1997, 152). Finally, foreign-owned and independent firms employed new, young workers with lower wages and pension and health care costs. They had no retired employees to support, and paid lower medical insurance than the Detroit 3 (Table 3). Moreover, to encourage migration and attract investments, local governments in Southern (non-union) states provided generous incentive packages on top of lower wages (U.S. Congress, Office of Technology Assessment 1992).

Table 3 Comparative Wage and Benefit Levels in the US Automotive industry, 1986

\begin{tabular}{lcccc} 
& \multicolumn{2}{c}{ Average hourly wage } & \multicolumn{2}{c}{ Total compensation including benefits } \\
& $\$$ & Index & $\$$ & Index \\
\hline Big Three assembly and in-house parts & 15.0 & 100.0 & 22.50 & 100.0 \\
Transplant assembly & 15.0 & 100.0 & 17.5 & 77.8 \\
PARTS -Independent US suppliers & 10.4 & 69.3 & 13.0 & 57.8 \\
PARTS -Transplant suppliers & 8.0 & 53.3 & 10.0 & 44.4 \\
\hline
\end{tabular}

Source: U.S. Congress, Office of Technology Assessment (1992)

Between 1978 and 1987, total employment in the US automotive industry fell by 200 thousand, from 1.311 to 1.131 million workers. By 1991 it came to barely above one million (1.036). The new geography of production and the shift away from in-house component manufacturing increased the share of the industry operating outside of traditional union structures - two thirds of the employment in independent parts was in non-union plants (U.S. Congress, Office of 
Technology Assessment 1992) - and widened the heterogeneity in the workplace. In this period of transition, as manufacturers worldwide started to shift from Fordist mass production to the new lean production introduced by Japanese carmakers we observe various combinations of conflict and collaboration: between companies and unions, between OEMs and their suppliers, and between US companies and their Japanese competitors. What seemed, in the 1990s, a massive overcapacity crisis was described by Jones, Roos and Womack in the new edition of The Machine that Changed the World as "an acute shortage of competitive lean-production capacity and a vast glut of uncompetitive mass-production capacity" (Womack, Jones, and Roos 2007).

\subsection{Impact of US developments on Mexico: from production for the domestic market to} production for export

The shock that hit the US automotive industry and the changes in the strategies of the US OEMs profoundly affected the Mexican industry. Up to the mid-1970s the five "legacy" automakers Ford, GM, Chrysler, Nissan, and Volkswagen - formed an oligopoly in a small domestic market protected by high entry barriers. Local content and trade balance requirements had forced carmakers to develop a local network of suppliers of parts and components. However, these plants operated on a low-volume, kit-assembly framework. Parts producers lacked the economies of scale and the expertise to invest in the development of new products and technologies, and remained dependent on the strategies decided by the top management in core countries.

In the early 1980s, all three big US companies built new plants in Mexico closer to the US border to export vehicles and components to the United States. General Motors' assembly plant was designed to produce 500,000 six-cylinder engines per year; Chrysler's plant in Coahuila was planned to produce, in the first stage, 270,000 engines, 220 thousand of which were to be exported to the US (Castellanos Elías 2016). Chrysler's relocation of its plant from the State of Mexico to the North was also driven by labor costs and personnel discipline considerations: daily wages in Coahuila were between $\mathrm{Mx} \$ 90$ and 98 , compared with $\mathrm{Mx} \$ 450$ in Mexico City, the workers were younger and with less union experience, and "protection contracts"5 insured

5 The so-called 'protection contracts' are "collective bargaining agreements signed between management and state-allied unions (official unionism) long before a plant opens. In practice, they operate as company contracts, and thus when a plant opens and workers are hired, they are faced with a union and a contract they neither voted for nor were aware of. In addition, firms are allowed to define the rules of work and labor compensation at the plant level, so trade unions have no way to counter the 'race to the bottom', on wages, at either the company or the regional level" (Covarrubias 2020, p. 336). 
foreign companies against wage increases. Unlike in the past, the new plants implemented the new, state-of-the-art organizational and production techniques learned from Japan. The Ford plant at Hermosillo, for instance, adopted lean-production techniques and had been rated among the best plants by the MIT team (Womack, Jones, and Roos 1990).

The disruption produced by lean production in the US plants also affected non-US automakers producing in the US. Such was the case of the VW mass-production assembly plant in Pennsylvania (established in the 1970s), which was operating at 50\% of capacity in 1987 (VW, 2014). VW closed the plant, transferred the presses and moved production of the Jetta and Golf models to Puebla to defend its standing in the Mexican market. Conversely, Renault sold to Chrysler its US facilities - which it had bought from American Motors in 1979 - and abandoned Mexico in 1986.

The automotive parts industry also saw profound transformation, with the growth of two separate segments: the maquiladoras, producing parts for re-export, and a segment more connected with the assemblers, producing for the Mexican market and for export. Production of automotive parts in the maquiladoras - wire harnesses, seat covers, electrical components, plastic parts, brake parts and heating, ventilation and air-conditioning components - took off in the 1980s, catalyzed by the plummeting Mexican peso (the exchange rate went from 26 to around 3,000 to the dollar between 1982 and 1987). In 1980, there were approximately 13 thousand workers employed in maquiladora automotive parts production, 8 percent of total maquila employment, in 41 plants. By 1993 they were 90,000, 16.5 percent of total employment, in 122 plants (INEGI, IMMEX). They competed in labor-intensive productions hard to automate, the sort of work that could be performed by low-skilled labor with little training (Figure 2). 
Figure 2. Share of total automotive, assembly and parts in manufacturing GDP, 1970-1996.

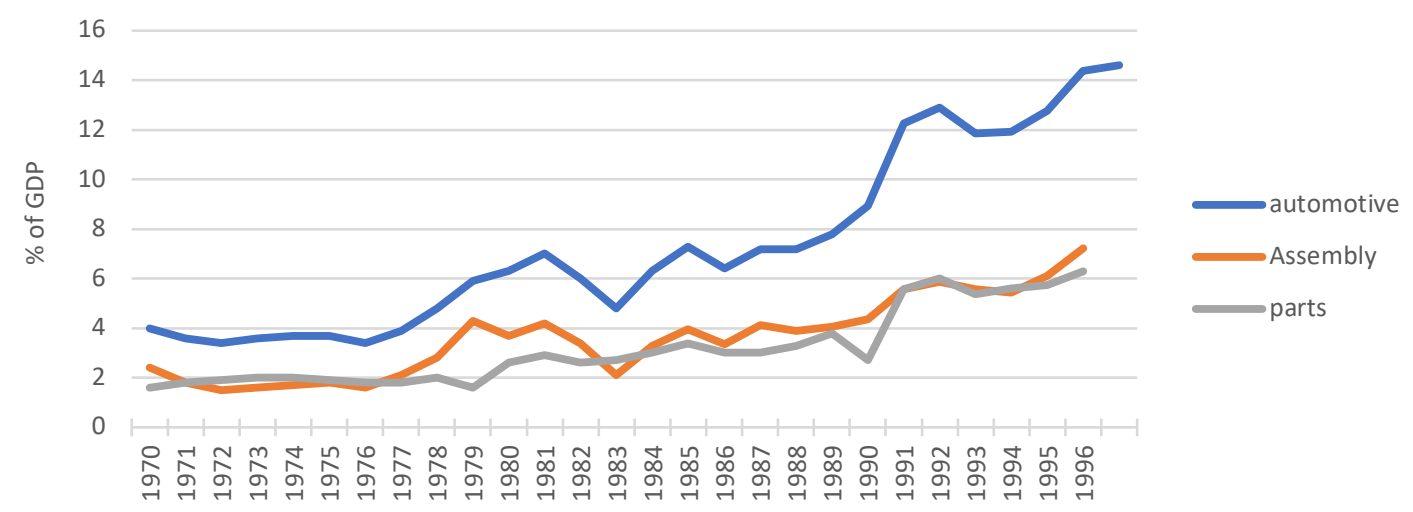

Source: INEGI. Industria Automotriz en México

In the 1980s, assembly plants in Mexico either produced parts internally or outsourced production to trusted suppliers near the assembly facilities, often owing their existence to strategic alliances with major US auto parts manufacturers. There were several foundries capable of producing complex castings at competitive cost and quality and the OEMs opened plants to produce engines: they were easy to ship but not labor-intensive, and components like pistons and valves had low shipping costs and could be imported.

Eventually, the industrialization process seemed to find a rationale in the Mexican automotive industry - an outcome that leaves open the question of the benefits of an industrialization process dependent on global players. A number of studies explored the existence and intensity of linkages with the local economy, the emergence of local companies, the transfer of knowledge, and the role of local institutions and organizations to support the upgrading of the local suppliers. The insufficient development of the domestic value chain, in terms of both coverage of the various stages and technological and qualitative capabilities, were highlighted by several authors (Castellanos et al. 2010; Carrillo 2018; Arteaga et al. 2019). However, in their study of the supplier network in the automotive cluster led by Ford Motor Company in Hermosillo, Contreras, Carrillo and Alonso (2012) found that a new trend of knowledge-intensive, small local companies had emerged, providing higher-value services and playing more important roles in the supply chain. We shall return to this issue in section 6. 


\section{The North American Free Trade Agreement}

In 1992 there were two leading positions among the negotiators of the North American Free Trade Agreement (NAFTA). One argued that NAFTA would mean higher economic growth and increased prosperity for the three signatory countries, the United States, Canada and Mexico. Two main arguments - allocative efficiency and scale economies - underpinned the case for free trade. The first argument was based on factor endowments: if the United States and Canada specialized in the production of capital-intensive goods and Mexico in the production of laborintensive ones, all would benefit from free trade. The second argument focused on the creation of a large integrated market to reduce costs and increase productivity. The conclusion was that NAFTA would improve efficiency in the area and raise living standards in Mexico.

Conversely, the other position feared the unleashing of brutal competition based on low wages and worsening working conditions on both sides. The main exponent of this position on the US side was the AFL-CIO, who warned that what was at stake was not trade with Mexico, but the nature and quality of that trade. Cost-cutting efforts by US corporations had already produced a shift of production facilities from the Rust Belt to Northern Mexico. The Treaty could increase the rush to cheap Mexican labor, leading to deindustrialization and technological stagnation in the US without benefiting labor in Mexico. The US Congress Office of Technological Assessment (U.S. Congress, Office of Technology Assessment 1992, 3) joined the skeptical voices, warning that market forces alone were not likely to produce significant social and economic rewards in a free trade area. The Mexican government, on the other hand, was counting on closer market integration to sustain the development of the domestic automotive industry, perhaps underestimating the problems associated with its control.

The optimistic view prevailed, and the Treaty was signed in 1992 by Canada, Mexico, and the United States to take effect on January 1st, 1994. It provided for a gradual reduction of duties and tariffs ${ }^{6}$, down to zero by 2004 , and set at 62.5 per cent the minimum domestic content for duty-free exports. The threshold was raised from a previous 50 percent requirement to keep

6 The tariff concessions made by Mexico were more significant than the benefits obtained. Indeed, although liberalization had started long before NAFTA, the average Mexican tariff was still $10 \%$, compared with $2.1 \%$ in the US. Half of the Mexican exports were exempted from US tariffs under the Generalized System of Preferences (GSP) and the maquiladora program; the rest of Mexican exports paid an average tariff slightly above 4\%. After the agreement, in 1996, the average tariff in Mexico was $2.9 \%$, compared with $0.61 \%$ in the US; not only was the US reduction modest, but it should have applied in any case following the Uruguay Round. The Mexican authorities also expected that a trade agreement would remove the nontariff barriers widely used by the U.S. to restrict imports of competing goods. 
foreign automotive producers (in particular Japanese carmakers) from using Mexico as an export platform for selling into the United States (Klier and Rubenstein 2017). Foreign ownership was completely liberalized and extended to parts and components plants. By 2004, most of the trade barriers of the import substitution period had been eliminated.

Since joining NAFTA, Mexico has also signed various other free trade agreements, which increased the attractiveness of the Mexican location, offering duty-free exports as well as cheap labor. In particular, a treaty with the European Union, signed in 2000 "despite the resistance of American firms" (Volkswagen de México 2014), gave Europeans the same conditions enjoyed by the Americans. Smitka and Warrian (2016) give the example of Audi. As a producer of premium vehicles, if located in the US Audi would pay a 10\% tariff on exports to Europe; locating the plants in Europe would imply tariffs on exports to the US and other countries. The Mexico location would allow tariff-free exports to both regions. Moreover, with the development of modular architecture, Audi could share components with Volkswagen, its parent company which had developed a vast network of parts suppliers. Audi located its new plant at Puebla, 30 km from the biggest VW plant outside Germany. Mexico's geographic position offered a further advantage in terms of location: close to the vast American market and the world's main consumption centers, measuring distance by maritime days. Despite these advantages, the markets outside the NAFTA area did not represent a concrete alternative to the almost monopsony of the United States on Mexican production. In the 2000s, exports to the North American region were still 80 percent of total automotive exports, while Europe accounted for only $5 \%$ and has remained around that figure ever since.

\section{Trade agreements and the regionalisation of world production}

The NAFTA Treaty aimed at the creation of a vast market, shielded from foreign competition by tariffs and regional content requirements. The latter mainly affected non-US automakers, who had to set up domestic production of the parts and components previously imported from their own home country (basically Germany and Japan) ${ }^{7}$. On the Mexican side, there was also the hope that the Treaty would attract to Mexico non-US firms eager to export to the US market. However, in the aftermath of the Treaty, with the exception of Honda and Toyota, FDI

7 To avoid the closure of facilities at Puebla (VW), Cuernavaca and Aguascalientes (Nissan), the regional content requirement was applied gradually. 
concerned mainly the legacy automakers and suppliers of parts and components (Figure 3). It was not until after the 2008 crisis that a new, more substantial wave of entry occurred. The lack of response by new OEMs may be the reason why in 2003, a year before full liberalization, a new decree ${ }^{8}$ was brought in to encourage FDI, streamlining registration of new OEMs and relaxing constraints on imports, provided that they committed to invest in physical infrastructure, training, and transfer of technology to their suppliers.

\section{Figure 3. Investment in motor vehicle (car and truck) production and parts and components for motor vehicles (NAICS 3361 and 3363), 1999-2019.}

Millions of US dollars

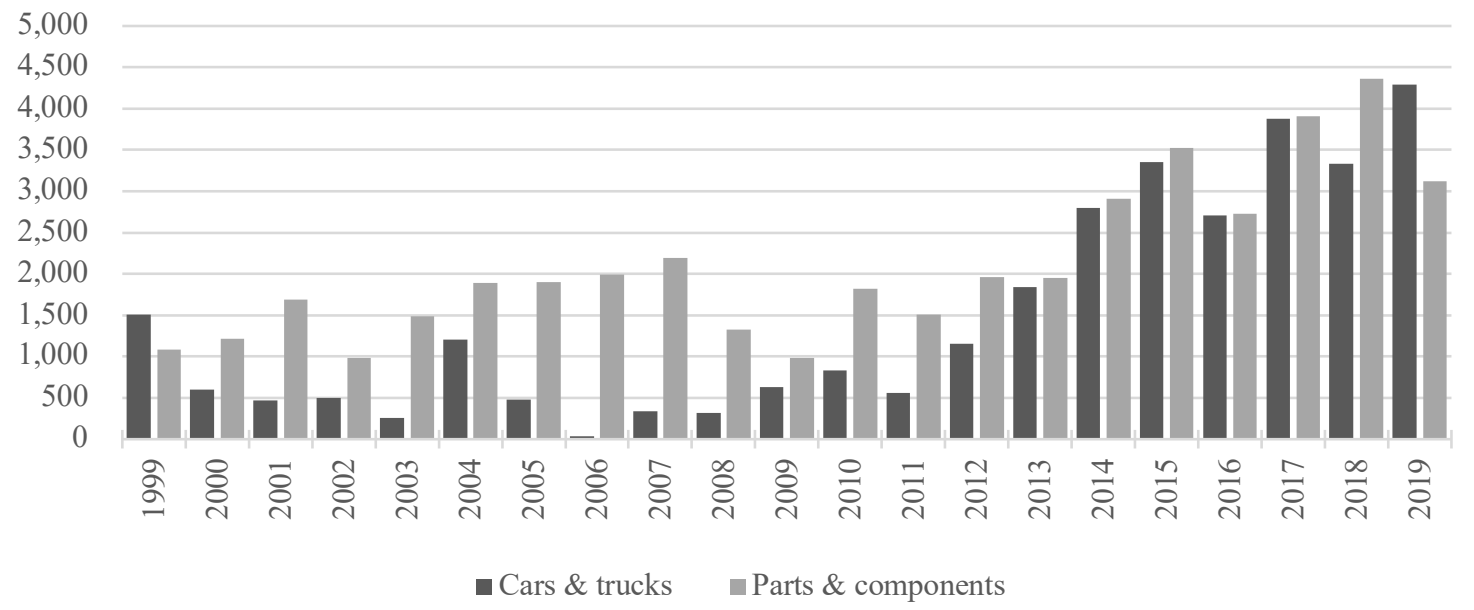

Source: Secretaría de Economía.

Vehicle production in Mexico grew in two stages: it doubled, from 1 to almost 2 million vehicles between 1993 and 2000, ${ }^{9}$ and fluctuated around that level until the 2008 crisis. It was in the postcrisis period that production took off, doubling again between 2007 and 2018 from 2 to 4 million (Figure 4). With domestic demand stagnating ${ }^{10}$, exports became the preponderant part of the

8 The "Decree to Support the Competitiveness of the Terminal Automotive Industry and the Development of Domestic Market for Automobiles" (2003) aimed to: a) stimulate the inflow of investments to build or expand assembly facilities and cut costs of imports through tariff reductions in Mexico; b) allow registration of new OEMs in Mexican territory for investments that were higher than US\$100 million and were to produce at least 50,000 vehicles per year during a three-year term; c) lift tariffs on imports of cars for values equal to $10 \%$ of the production of the previous year; d) allow greater volumes of vehicle imports on condition that firms increase their investment in infrastructure, training and R\&D programs, develop local suppliers and transfer their technologies to first and second-tier suppliers.

9 Passenger car production increased from 835.3 thousand in 1993 to 1.28 million by 2000; Truck production went from 219.9 thousand in 1990 to 648.2 thousand by 2000 (INEGI, BIE, Comunicaciones y Transportes).

10 In 1994, a severe currency and financial crisis depressed the economy for many years. A further blow to the domestic market for cars was delivered by President Vicente Fox, who, in a political move to gain votes, liberalized import of used cars. 
production, reaching $84 \%$ in 2018 , and the trade balance turned into an increasing surplus (from 5.1 billion dollars in 1993 to 78.6 billion in 2019), mainly due to exports of finished vehicles. Most exports headed to the United States ${ }^{11}$ : the country had become an export platform, the integrated periphery of the United States.

Figure 4. Mexico. Production of motor vehicles (columns) compared to domestic sales of passenger cars and trucks and exports of light vehicles, 1988-2020.

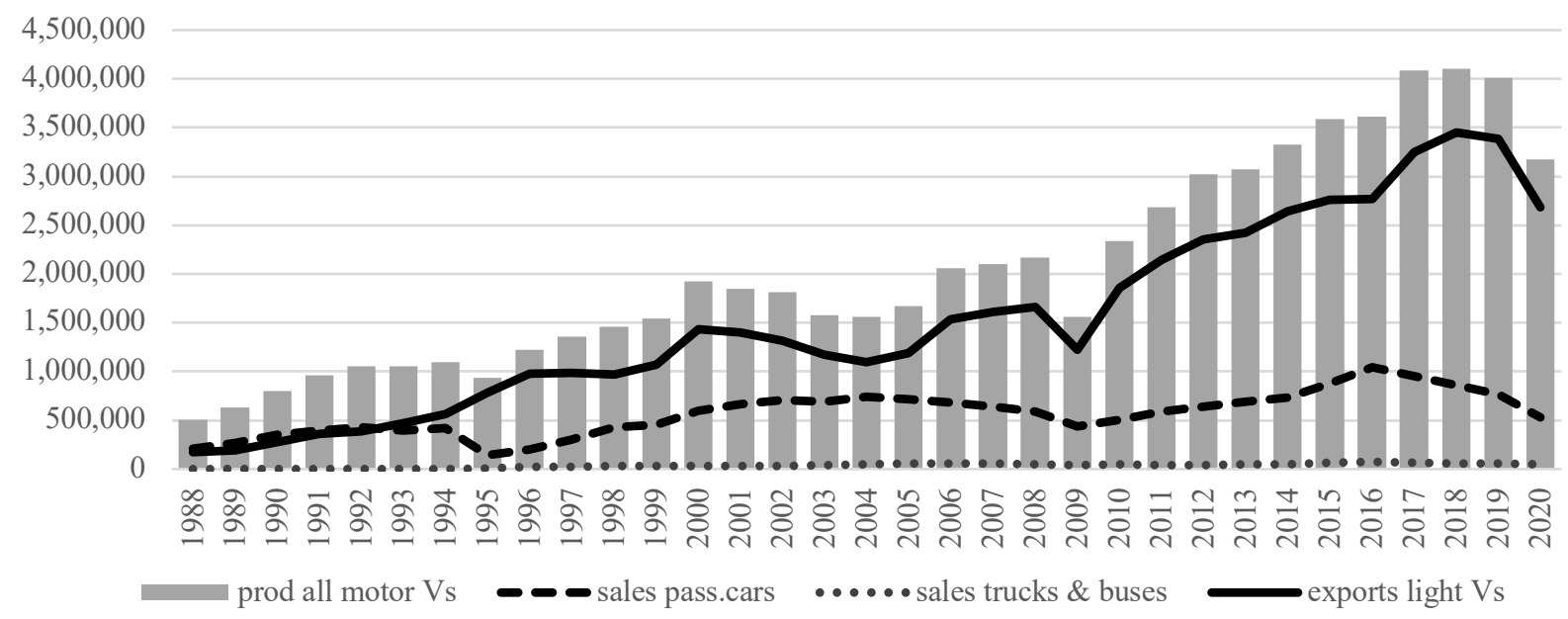

Source: INEGI, https://www.inegi.org.mx/sistemas/bie/\#D10900540, Registro Administrativo de la Industria Automotriz.

Explanation of the delayed response of FDI and production is to be found in the geographic reorganization of the industry at the global level. When the Trade Agreement was signed, in 1993, the main OEMs were consolidating their spatial strategies. In the North-American macroregion, the Japanese producers had opened their plants in the US back in the 1980s, to counter the protectionist policies of the US government; conversely, German carmakers (BMW and Mercedes-Benz), while opening plants in the US in the 1990s, continued to serve the market mostly through exports. The different strategies of Asian and European OEMs are reflected in the different reliance on imports into the United States. Even in 2017, Japan-based carmakers were still importing from Japan $25 \%$ of the vehicles they sold in the United States; Europe-based carmakers imported 59\% of their US sales from Europe, and Korea-based carmakers (Hyundai

Almost 4 million used cars were imported between 2006 and 2008 (Brincks, 2018), depressing demand for new vehicles until after 2010 .

11 Mexico's weight in US imports of automotive and parts is increasing continuously, as is the US bilateral deficit. In 2012 Mexico ranked 3rd in US vehicle imports, after Canada and Japan, and dominated in the auto parts segment, with a $35 \%$ share, followed by Japan and Canada, with 13.12\% and 13.05\%, respectively (Dussel Peters and Gallagher, 2013). 
had opened a plant in 2005) 48\% of their US sales from Korea. Three full-scale assembly plants were opened in Mexico in the early 1990s (one each by Chrysler, GM, and Nissan). The "legacy" producers would remain the only OEMs active in Mexico until 1994, when Honda and Toyota began production in Mexico - at small-scale plants in El Salto (in 1995) and Tijuana (in 2004), respectively - to meet NAFTA's requirements that some production be located in Mexico in order to be able to import vehicles (Klier and Rubenstein 2017). The new plants adopted the latest technology and became essentially interchangeable with those in the United States and Canada.

A similar process of restructuring and geographical reallocation was taking place in Europe. In the 1980s, the looming threat from Asian vehicle producers scared industry leaders and policymakers. Sales of Japanese imports were subject to quotas. Tokyo agreed to monitor its exports to the European Union and allow them to increase only gradually. In 1992, as Europe moved toward a more open market, European trade officials had agreed to gradually allow the Japanese a greater portion of the market, but when sales slumped the following year, and European carmakers feared a permanent loss of market share, Japan was forced to accept slower growth. In exchange, Europe agreed that it would lift all restrictions by the year 2000. In addition, Japanese cars built in Europe had to contain $60 \%$ of parts made in Europe. Finally, a European system of car dealerships almost as highly regulated as the Japanese system made it virtually impossible for the Japanese to sell through existing dealers. The effectiveness of this protection is demonstrated by the cross-country difference in the Japanese market share: in Italy, for example, where Fiat struggled to stay in the race, the Japanese share had been held to about 5\%; in France, where auto makers Renault and Peugeot effectively lobbied the Government for protection, it was less than $4 \%$. In relatively open markets, the Japanese share was much higher: $24 \%$ in Switzerland, 37\% in Ireland, 29\% in Finland, 26\% in Denmark (Tagliabue 1995). Concern grew also over Korean automobile imports, with French carmakers setting off alarm bells about the risk of a Korean tidal wave. Korean carmakers circumvented the protectionist measures by opening plants in Eastern Europe.

Since the 1990s, following the fall of the iron curtain first, and then the Eastern enlargement of the European Union, massive relocation of production eastward has allowed the main European OEMs, and especially the German ones, to take advantage of the creation of the Common Market and meet the challenges represented by Japanese and, later on, Korean transplants 
(Brincks et al. 2018). Unlike in the US, however, these processes contributed to reinforcing the competitive position of the lead country and its 'national champions'. In fact, compared to the US, German companies offshored a higher share of components and small cars, while retaining at home a higher share of assembly and production of premium cars (Simonazzi et al 2020).

Thus, although production facilities in Europe and North America have been increasingly located in peripheral regions - Central Mexico in North America and former Communist countries in Central Europe - the consequences on production and employment in the core countries have differed substantially. Cheap labor, geographic proximity to large markets, membership in regional trade agreements, and investment incentives lie behind the growth of an automotive industry in these countries and the simultaneous restructuring in both traditional core regions and old integrated peripheries in Western Europe and North America. By the turn of the century, the motor vehicle industry had become global in terms of ownership of carmakers, but it was actually highly regionalized in terms of production and sales. Although all of the leading companies produced and sold vehicles in more than one region, only less than $10 \%$ of vehicles were produced in one world region and shipped for sale in another (Brincks et al. 2018), whilst cross-region trade in parts and components increased (Russo, Alboni, De Domenico, et al. 2021).

The 2008-09 crisis marked a watershed in the automotive industry. It almost bankrupted many OEMs, triggering restructuring and closure of plants. The NAFTA region lost $32.4 \%$ of its production (from 12.9 to 8.7 million vehicles). The US carmakers had to be bailed out by the government. Thanks to a government-managed reorganization of Chrysler and General Motors during 2009, the two carmakers emerged from bankruptcy protection with lower labor costs, higher capacity utilization, and a more concentrated geographic distribution of assembly plants (Klier and Rubenstein 2013). While several plants closed, especially in the traditional automotive zone in the United States, others opened, the new industrial zones in Mexico being the most favored. Nine plants (out of eleven in the entire North-American macro-region) opened or set to open in Mexico between 2010 and 2020. Of these, only one was constructed by a Detroit 3 OEM (specifically Chrysler, in 2013). Five were Asian automakers - Mazda and Nissan (2013); Honda (2014); KIA (2016); Toyota 2020 - which invested in Mexico in order to sell in North America. The remaining three were German luxury auto manufacturers: VW's Audi (2016), Daimler's Mercedes-Benz (in conjunction with Nissan's Infiniti) (2017); and BMW (2019)(Klier and Rubenstein, 2017, table 11). 
European producers were also badly hit by the crisis, although with different degrees of severity. An agreement for a gradual reduction of European production capacity along the lines of the American example, as advocated by the Fiat's CEO, Sergio Marchionne, was impossible because of the involvement of many states, each determined to defend their industry and their jobs, and above all by the stern opposition of the German OEMs, which had been able to overcome the crisis thanks to the booming exports of their premium brands to China (and the US). The expansion of the Chinese market and the stagnation of the European one were important factors affecting the new location strategies of the OEMs.

In addition to regional reorganization, another factor lay in the intensification of monopolistic competition in a saturated market, which resulted in proliferation of models, lower volumes and declining profitability. The introduction of modular architecture allowed for the sharing of core components across vehicles and differentiation of vehicles sharing one chassis, thus reducing costs. In addition, companies attempted to create common production protocols for their factories and their suppliers. Modularity and body-on-frame allowed not only for greater variety, but also for greater flexibility in the location of production and in the choice of the country from which to serve the market: a particular product could be made only in one country and exported elsewhere, a process whose advantage is greatest where tariffs are zero or very low.

Thanks to lower labor costs, proximity to the US market, and tariff agreements, Mexico became a truly advantageous location: the only country, with the exception of Canada, to ensure dutyfree entry into the US market and with numerous trade agreements covering world markets. The US regulation to limit greenhouse gas (GHG) emissions treated trucks more favorably, thereby creating an incentive to transform large "cars" into "trucks"12 (Smitka and Warrian 2016); consequently, US sales of cars declined, and sales of light trucks soared. We observe a corresponding change in the composition and differentiation of vehicle production in Mexico, increasingly specialized in small-medium-size cars and large pick-up trucks. The two productive systems have become integrated, "to such a degree that we could refer to a regional auto parts-

12 The Corporate Average Fuel Economy (CAFE) set fuel efficiency standards regarding emissions and imposed heavy fines on manufacturers whose cars exceeded emissions limits. However, the standards were less strict for trucks. Two-wheel drive SUVs under 6,000 pounds GVW are classified as cars, while most SUVs that have four-wheel drive or are above 6,000 pounds GVW are considered trucks. SUV models that are less than 6,000 pounds GVW can have both car and truck variants, with two-wheel drive versions classified as cars and four-wheel drive versions classified as trucks (U.S. Department of Transportation, Federal Highway Administration, Bureau of Transportation Statistics). 
automobile chain with regional models, inputs, products and processes" (Dussel Peters and Gallagher 2013).

Pursuit of alliances, buyouts and fusions in particular characterized the consolidation of the industry to rationalize production, and guarantee the presence and variety in the global markets. MNCs started to invest in China as from the 1980s and the expansion of joint ventures started in 2001 (Smitka and Warrian 2016), while ensuring a position in each of the three main regions from where to serve the market.

\section{Wages and employment}

With the elimination of tariffs in the regional trade, labor cost differentials were the major factor expected to guide the reallocation of production and labor and lead to the convergence of wages. In $1995,84 \%$ of the light vehicles sold in the United States were assembled in one of the three North American countries. In 2016, the share was still as high as 78\%, but the distribution of production within the macro-region had changed considerably. Mexico's share of North American production increased from $6 \%$ in 1995 to $11 \%$ by 2000 and $20 \%$ by 2015 ; production in the USA declined from $78 \%$ to $67 \%$ and in Canada from $16 \%$ to $13 \%$.

Employment in transport equipment in Mexico grew much faster than in manufacturing: between 1988 and 2018, the number of employees in the sector increased tenfold, to 1.3 million ${ }^{13}$, its share in total manufacturing growing from 5.1 to 20 percent (Table 4). After peaking at the turn of the century, US employment fell by almost 500 thousand persons in the following decade, rising back only to the 1990 level (Figure 5). The loss of jobs in the United States as from the end of the 1970s (from 1.5 million to 953,000 in 2017) hit membership of the UAW, which dropped from 1 million to 355,000 by 2016 (Covarrubias and Perez, 2020, 473).

13 Between 1988 and 2018 employment in manufacturing trebled from 2,782 to 6,493 thousand. In 2013, 718,600 persons were employed in manufacturing cars and trucks and 592,000 in the parts and components industry. In 2019 the figures were 1,055,300 and 866,000 respectively. In 2016 Mexico had 61,100 workers in vehicle assembly and 674,372 in parts production; by comparison, employment in the U.S. motor vehicle industry totaled 760,800 in 2016 (180,900 in vehicle assembly and 579,900 in parts production (Klier and Rubenstein 2017). 
Table 4. Employment and business units in manufacturing (NAICS 31-32) and transport equipment (NAICS 336), 1988-2018.

Manufacturing industry (NAICS 31-32)

\begin{tabular}{|c|c|c|c|}
\hline YEAR & $\begin{array}{c}\text { Employment } \\
\text { (number of } \\
\text { persons) }\end{array}$ & $\begin{array}{c}\text { Business } \\
\text { units } \\
\text { (number) }\end{array}$ & $\begin{array}{c}\text { Average } \\
\text { employment } \\
\text { (number of } \\
\text { persons) }\end{array}$ \\
\hline
\end{tabular}

\begin{tabular}{llll}
\hline 1988 & $2,781,659$ & 167,793 & 16
\end{tabular}

$1994 \quad 3,444,518 \quad 334,133 \quad 10$

$1999 \quad 4,175,400 \quad 342,659 \quad 12$

$2004 \quad 4,198,579 \quad 328,718 \quad 13$

$20094,661,062 \quad 436,851 \quad 11$

$2014 \quad 5,073,432 \quad 489,530 \quad 10$

$2018 \quad 6,493,020 \quad 579,828 \quad 11$
Transport equipment (NAICS 336)

\begin{tabular}{ccc}
\hline $\begin{array}{c}\text { Employment } \\
\text { (number of }\end{array}$ & $\begin{array}{c}\text { Business } \\
\text { units }\end{array}$ & $\begin{array}{c}\text { Average } \\
\text { employment }\end{array}$ \\
persons) & (number) & $\begin{array}{c}\text { (number of } \\
\end{array}$ \\
\end{tabular}

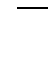

$136,912 \quad 136$

$167,221 \quad 1,498 \quad 112$

$434,836 \quad 2,220$

196

259

245

325

398

1,978

2,203

2,392

3,250

2

\% employment

transport eq. / manufactur. industry

ing
$\%$
business units transport eq. / manufactur. industry

Source: INEGI. Economic Census (1989, 1994, 1999, 2004, 2009, 2014, 2018) 
Figure 5. US employment in motor vehicles and parts manufacturing. 1990-2020

Annual average employment (thousands)

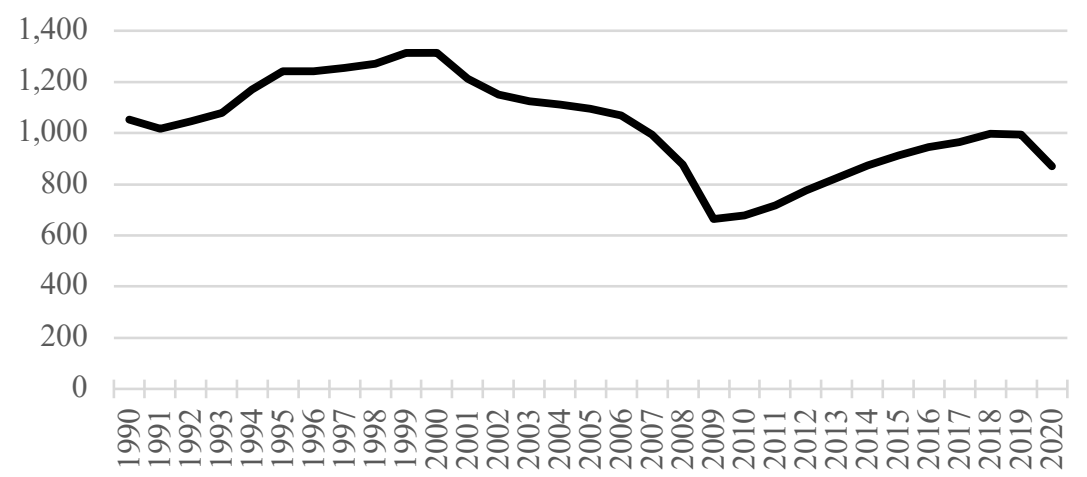

Growth rate \%. Not seasonally adjusted.

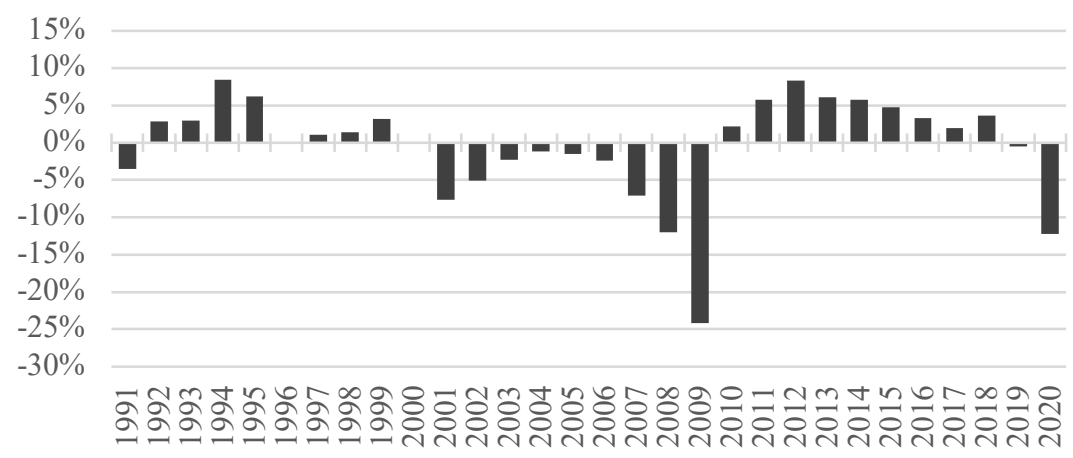

Source: Bureau of Labor Statistics

The divergent trend in employment contrasts with the homogeneous trend in wages. Although Mexican wages in the automotive sector are higher than the average wage in manufacturing - the assembly sector pays more than twice the average wage in manufacturing, with parts and components coming slightly above it - their rate of growth has been disappointing (Table 5). "Protection contracts", and "official unionism" have proved highly effective in containing the demand for wage increases and labor conflicts, despite the skilled labor shortages ${ }^{14}$. The labor legislation reform of 2012 aimed to increase employment and promote productivity and competitiveness by increasing labor market flexibility: it authorized outsourcing as a legal form of contract and allowed new fixed-term contracts to be brought in; moreover, it supported the

14 A decentralized public organization created in 1962 - the Comisión Nacional de Salarios Mínimos (CONASAMI) - in charge of determining the minimum wage, has indirect effects on wages in the automotive sector mainly as a reference for wages paid in the industry. In 1984, the income of a wage earner was, as a general average, 1.5 times the official minimum wage. 
workers' right to be hired and promoted and made labor training compulsory, while cutting the cost of dismissal without legal cause.

Table 5. Average Annual Wages Paid in Manufacturing Industry in Mexico. 2003-2017

Wages paid in subsector 336 and industries 3361 and 3363 as percentages of the average wage paid in the manufacturing sector. Wages are calculated in dollars at the FIX exchange rate determined by Banco de México

\begin{tabular}{ccccc}
$\begin{array}{c}\text { Total sector } \\
\mathbf{3 1 - 3 3} \\
\text { manufacture }\end{array}$ & $\begin{array}{c}\text { subsector 336 } \\
\text { Transport equip. }\end{array}$ & $\begin{array}{r}\text { subsector 3361 } \\
\text { passenger cars } \\
\text { and trucks }\end{array}$ & $\begin{array}{c}\text { subsector 3363 } \\
\text { parts and } \\
\text { components }\end{array}$ \\
\hline $\mathbf{2 0 0 3}$ & $\$ 5,588=100 \%$ & $\$ 7,610=136 \%$ & $\$ 13,535=242 \%$ & $\$ 7,011=125 \%$ \\
$\mathbf{2 0 0 5}$ & $\$ 6,137=100 \%$ & $\$ 8,229=134 \%$ & $\$ 16,957=276 \%$ & $\$ 7,341=120 \%$ \\
$\mathbf{2 0 1 0}$ & $\$ 6,617=100 \%$ & $\$ 9,424=142 \%$ & $\$ 18,675=282 \%$ & $\$ 8,014=121 \%$ \\
$\mathbf{2 0 1 5}$ & $\$ 6,725=100 \%$ & $\$ 8,675=129 \%$ & $\$ 14,973=222 \%$ & $\$ 7,899=117 \%$ \\
$\mathbf{2 0 1 6}$ & $\$ 6,095=100 \%$ & $\$ 7,855=129 \%$ & $\$ 12,990=213 \%$ & $\$ 7,243=119 \%$ \\
$\mathbf{2 0 1 7}$ & $\$ 6,397=100 \%$ & $\$ 8,406=131 \%$ & $\$ 14,102=220 \%$ & $\$ 7,638=119 \%$
\end{tabular}

Source: www.inegi.org.mx/sistemas/bie/

Wages in the auto sector did not fare well in the US either: Covarrubias (2020, p. 335) estimated that, in the 23 years of NAFTA, US and Canadian auto industry wages decreased from $\$ 36$ to $\$ 27$ and from $\$ 34$ to $\$ 26$, respectively. Not only did the Treaty fail to lead to a convergence in wages - in 2019 the average hourly wage in the US was still eight times the wage in Mexico but dragging wages down became an entrenched feature of the industry in the NAFTA region. A study of the largest exporting economies conducted by The Boston Consulting Group (2014) indicates that, since the beginning of the new century, the United States and Mexico have recorded the lowest growth (strictly negative) in wages. Mexico is the most cost-competitive (i.e., low-cost) manufacturing country amongst the leading ten export economies (lower than the Chinese and Brazilian ones, and higher only than the Indian), while the United States occupies the fourth place, after China and South Korea (Covarrubias and Perez 2020, 472).

Whether the blame for falling wages should fall specifically on NAFTA or is to be imputed to a general trend caused by the pressure exerted by outsourcing of production and jobs at the world level is debatable. The threat represented by lower-cost locations is used to kill wage increases 
across the entire production network. Delocalization, interplant competition and threats of relocation of production have also put pressure on higher-wage core countries, such as Germany, where shifts in jobs to low-wage countries have resulted in concession bargaining at many automotive supplier locations to prevent relocations or gain new products for the plant. Competition over labor costs and government incentives have been an important driver of the dynamic nature of a nation's competitive position within the automotive production networks (Simonazzi, Carreto-Sangines, and Russo 2020).

The new USMCA Treaty tried to limit the rush to wage devaluation and defend US jobs. It set new rules concerning workers' rights - the right to free association and collective negotiation and Labor Value Content (LVC) rules for vehicles ${ }^{15}$. It also redefined Regional Value Content (RVC) requirements for vehicles and auto parts, steel and aluminum purchase requirements, and new content provisions for specific sectors.

The Labor Chapter represents a significant departure from NAFTA, which addressed labor rights only in a side agreement. The rules regarding the Labor Value Content require that $40 \%$ of the total cost of passenger vehicles and $45 \%$ of the costs of light trucks pay wages of at least US\$16 per hour ${ }^{16}$. Unlike in Mexico, in the United States and Canada many plants in final assembly, engine, and transmission already pay the wage level required by the Treaty. Strengthening labor standards and workers' rights, including collective bargaining, the Agreement could promote higher wages and better labor conditions in Mexico (as well as in the US). Thus, it is estimated that, if fully implemented and enforced, the labor code could have a significant effect on reshoring (USITC and Torsekar 2019; Klier and Rubenstein 2020). ${ }^{17}$ To comply with these labor requirements, a new Labor Law was approved by the Mexican Congress in 2020. In addition to recognizing the right for workers to use collective bargaining, in November 2020, the Mexican

15 The USMCA labor chapter requires the parties to adopt and enforce the workers' rights defined by the International Labor Organization. It seeks to protect migrant workers, address violence against workers and imports produced with forced labor, prohibits the elimination or weakening of existing labor regulations. USMCA labor provisions are subject to a dispute settlement mechanism.

16 There are three components: 1) expenditure on technology may represent up to $10 \%$ of Labor Value Cost (LVC); 2) a vehicle producer may receive up to $5 \%$ in credits for LVC if he can demonstrate that he assembles engines, transmissions or advanced batteries and that reaches a minimum capacity requirement in some other part of the trade agreement and pays a production wage of, at least, US $\$ 16$ per hour; 3 ) the additional $25 \%$ to $30 \%$ of the LVC proceeds from materials produced with high wages. These costs are calculated as a total of the annual value of parts and materials purchased in plants located in one or more of the countries within the Treaty and that are produced with a wage of at least US\$16/hour.

17 Managers of Mexican companies interviewed in 2020 were more skeptical about the actual ability of this rule to affect wages (Simonazzi et al 2020). 
Congress forbade labor outsourcing - a strategy used by companies to reduce labor costs and avoid paying employee benefits - to protect gig workers, causing a tremendous political stir.

The Regional Value Content (RCV) proviso, aimed at increasing the production of auto parts and employment in North America, is expected to require adjustments in the supply chain. While changes in the sources of essential inputs could result in higher costs, increase in import duties in case of non-compliance could weigh more on Mexican products, because of their greater specialization in small cars, which command lower profit margins. All things considered, in 2019, before the 2020 pandemic crisis, the U.S. Commission on International Trade estimated that the USMCA would increase US real GDP and employment, particularly among the less educated, as well as wages for workers of all educational levels.

\section{Conclusion}

\subsection{A dynamic hierarchical division of labor}

The rise of Mexico is reflected in the decline of Canada, which is gradually losing ground in exports to the United States (Russo et al., 2021). The changing fortunes of the two countries raise the question of the implications that opening an economy to a free trade agreement has on the localization strategy of firms and, ultimately, on the prospects of the industries of countries at different stages of development. This issue has recently been investigated in relation to the European automotive industry within the theoretical framework of core-periphery relations. The concept has a long tradition. In the current discussion a preeminent role is assigned to the presence of "national champions". The periphery is distinguished between two sub-categories: the integrated periphery and the semiperiphery. Integrated peripheries reflect the rise of the global industry, with centrally developed platforms which use a standard set of materials and components worldwide (Smitka and Warrian 2016). Mexico responds to most of the characteristics of integrated peripheries, as identified by Pavlínek (2018): smaller domestic markets, export-oriented assembly of inexpensive mass-market models and components, foreign ownership and control of assembly and Tier-ones, low labor costs, scant strategic functions, and weak activation of domestic suppliers.

A high degree of foreign control of the automotive industry by the core-based multinational companies (MNCs) is a feature also shared by semiperipheries. Following Mordue and 
Sweeney's (2020) definition, unlike the integrated peripheries, semi-peripheral automotive countries are home to a well-educated, relatively high-cost workforce and headquarter location of some large automotive parts suppliers. However, they lack many regional assets endogenous to the core, such as a domestically headquartered automaker, and the clustering of R\&D and managerial functions, with strong implications for strategic decision-making and technological, know-how, and managerial dependency. Semiperipheries also tend to retain significant (but declining) levels of automotive production but have proven incapable of attracting significant mandates for automotive R\&D. With the globalization of the industry, their competitive advantage has diminished throughout the 21 st century.

This classification, useful for offering a fresco of the regional recomposition of production, structured in relations of integration and dependence, should not obscure the differences between peripheries and core companies' responses. Our reconstruction of the developments in the Mexican automotive industry has highlighted how differences in the strategies of firms and governments in the core affect their future development as well as the qualities of the relations with their integrated peripheries. Back in the 1970s and 1980s, the Japanese threat threw the US auto industry into panic and triggered the US government's response. Relocation in the Southern non-unionized states in the US and sourcing from Mexico were among the industry's responses. As noted by Covarrubias and Perez (2020), "following four decades of penetration of the American market with the double strategy of importing and producing at home, European and Asian manufacturers were able to dominate the market. As such, the United States' auto producers became the only component of the TRIADs to lose control of their home market to auto manufacturers from other continents". The Detroit 3's share of US production declined from $87 \%$ in 1990 to $78 \%$ by 2000 and $52 \%$ by 2017 ; in the same year, the first three Japanese companies plus Hyundai accounted for $40.5 \%$. Of the 43 assembly plants active in 2018 in the US, 26 belonged to the Detroit 3, 13 to Asian companies (four each Honda and Toyota, two each Nissan and Hyundai, and one Subaru); BMW, VW, Daimler and Tesla had one plant each (Klier and Rubenstein 2020) ${ }^{18}$. The five legacy producers maintained control over production in

18 On the other hand, in light of the uncertainty over the future of NAFTA following the election of Donald Trump as U.S. President in 2016, several vehicle producers made changes to their product planning for North America: Ford canceled a new assembly plant to be built in Mexico, Fiat-Chrysler decided to move production of its full-size pickups from Mexico to the United States, and Toyota shifted the production of its Corolla from a plant under construction in Mexico to a plant being built in the United States (Klier and Rubenstein 2020). 
Mexico: in 2015 they accounted for $85.7 \%$ of total vehicles production, the Detroit 3 accounted for less than half (48\%), with Nissan and VW with 24.5\% and 13.2\%, respectively.

\subsection{Catching up?}

Creation of an independent domestic industry is a goal that has been pursued constantly by every Mexican government. Prohibition to import finished vehicles, minimum local content, and prohibition of foreign ownership are among the measures usually implemented by latecomer countries to protect an infant industry. A few countries, including Japan and South Korea, succeeded, many failed. Despite being the seventh largest world producer of motor vehicles, Mexico lacks a "national champion"19. Womack, Jones and Roos, (1990, Ch. 10) briefly considered the difficulties met by Mexico compared with South Korea's different outcome. Mexico's "industrial policy" has been geared towards maintaining those elements of comparative advantage - basically low labor costs and tamed industrial relations - deemed necessary to attract foreign production. However, it prevented the development of a domestic market, and subjected the decisions as to what, how and where to produce to the interests of foreign-owned companies. The integration of the North-American market has developed within a hierarchically ordered industry to suit the interests of the (US) OEMs, rather than the development needs of Mexico.

Would a different policy have made a difference? China's recent experience highlights the difficulty for a latecomer country to enter a mature oligopoly: the Chinese government has exercised tight control over its potentially huge market, limiting imports and FDI, banning exclusive foreign control by imposing joint ventures with local companies to promote their technological upgrade, and fostering competition between producers (foreign and domestic) to avoid being colonized, as were Mexico, Brazil and Argentina. Despite the apparent success - in a few years, China has jumped to the top of the world producers list (Russo et al. 2021) - the government's target of developing a domestic industry, capable of consolidating around a few 'national champions' has not succeeded, so far. What has emerged is a particularly unconsolidated industry, dominated by foreign brands, producing conventional high-end vehicles

19 There were approximately $600 \mathrm{~T} 1$ and $900 \mathrm{~T} 2$ and T3 producers in Mexico in 2019; however, of the approximately 90 of the top 100 global suppliers of parts and components with plants in the country, only one was a Mexican company (most of the ten remaining T1s with no plants in Mexico were Chinese companies) (INA - Industria Nacional de Autopartes 2019). 
with almost no exports (Smitka and Warrian 2016). Paba (2021) argues that the joint venture policy hindered the creation of national champions: exploiting the clout that brands still command, especially in the premium class, foreign producers could retain control of most of the huge increase in the domestic production and sales of traditional, internal combustion engines ICE-cars. Sales in China are now an essential part of the overall OEMs' production: in 2019 VW's production in China accounted for 38\% of its global production; GM's share was 45\% with similar values for Honda. The policy of China differs not only from that followed by Japan and South Korea, which bought foreign technology and developed their own brands, but also from that of Mexico: a huge domestic market, which allures and locks-in foreign producers, and a government policy determined to orient, and subsidize, the development of an innovative industry. China has invested heavily and well in advance of traditional carmakers in e-vehicles. However, after an initial phase of inertia, the OEMs have moved quickly, investing massively in the "new car", entering into joint ventures with Chinese start-ups to reverse-engineer the new technologies back in their own production sites (Russo, Alboni, Carreto-Sangines, et al. 2021). Whether the changes the industry is going through will allow Chinese manufacturers to leapfrog the current stage and control the new phase of electric and autonomous cars remains to be seen.

Since it entered the WTO in 2001, China outcompeted Mexico in the United States market and began to compete with the United States in the Mexican market ${ }^{20}$. However, Chinese competition in the automotive sector has remained quite limited and the expected (or dreaded) massive Chinese investments in Mexico have yet to materialize, although China's explosive production of motor vehicles, its even higher domestic consumption, the Chinese companies' rapid learning processes and past experience with other chains (such as the electronics and yarntextile-garment chains) suggest that the country could start exporting automobiles on a large scale in the near future.

\subsection{The road ahead}

The automotive industry is facing the transition to the production of electric vehicles and autonomous driving; automation, robotics and digitalization; new forms of car ownership and mobility. All these changes have the potential to reshape existing industrial geographies,

20 China's share of total United States imports expanded from $12 \%$ to $42.1 \%$ in $2000-2010$, and Mexico's fell from $13.22 \%$ to $6.51 \%$. 
affecting the relative advantage of integrated peripheries versus semiperipheries and of different regions within and between cores, as leading companies adopt new digital technologies and alter their component supply chains and sourcing practices.

Although the precise effects are unknown at the moment, this transformation will take place at different speeds in the core, semiperiphery and periphery. A large segment of the supply chain, connected with the internal combustion engine, is expected to disappear. The challenge for Mexican companies is to be integrated in the new supply chains and participate in the coengineering of the manufacturing process ${ }^{21}$, in the adaptation of models to different markets, and in the design and development of new, more efficient parts and components.

There are several obstacles along the way. First of all, US policy itself: US legislation designed to encourage re-shoring and US regulations interpreting the USMCA's car and truck content requirements could limit Mexico's future access to the US market, mitigating the potential benefit that derives from the nearshoring of productive investments from Asia. Furthermore, its success in securing free trade agreements could be substantially curtailed by new intra-Asian trade treaties, especially if the United States decides to join them. Nationally, Mexico's longstanding problems - poor infrastructure, legal system and corruption - could reduce Mexico's attractiveness to foreign investment (Schott, 2021). One should note, however, that the Mexican governments have invested considerable resources in the development of domestic production and competence networks. The automotive suppliers in Mexico are now organized around a national network of clusters (Red Nacional de Clusters de la Industria Automotriz). There are nine regional organizations - Clusters - whose mission is to facilitate the collaboration between industry, government and research institutions to boost the competitiveness of the regional automotive sector. Governments and companies have put considerable effort and money into forming and training qualified engineers, technicians, and workers to fill the shortage of technical talent - in engineering, advanced software, materials and manufacturing - still plaguing the industry. The numerous signs of regional vitality, the recent wave of FDI in Mexico, besides the degree of integration reached by the Mexican and US industries, may justify some optimism

21 Volkswagen, for example, in 2009, invested in designing a vehicle for the North American market. It was the first time that Mexican engineers had participated in the technical design of the New Jetta at Puebla, and in 2013 opened a new plant at Silao, Guanajuato, to produce engines. The new models were built following the MQB platform (Modularen Querbaukasten or Modular Transverse Matrix), which allows Volkswagen to assemble a wide range of models on a common enginemounting core for all different power trains (Volkswagen de México 2014). 
for the future of the Mexican automotive industry in the Electric vehicles era, although the transformations required in its supply chain may be very costly. 


\section{References}

Arteaga, Arnulfo, Álvaro Bracamonte, Fernando Camacho, Jorge Carrillo, Gerardo González Herrera, Jordi Micheli Thirión, and (Roma Analysis Team "Equipo Roma”). 2019. "El Auto Del Futuro y El Futuro de México.” Comercio Exterior-Bancomext, no. 18 (June).

Benneth, Douglas, and Kenneth Sharpe. 1981. "El Control Sobre Las Multinacionales. Las Contradicciones de La Mexicanizacion." Foro Internacional 21 (4 (84)): 388-427.

Brincks, Corey, Boles\law Domański, Thomas Klier, and James M Rubenstein. 2018. "Integrated Peripheral Markets in the Auto Industries of Europe and North America." International Journal of Automotive Technology and Management 18 (1): 1-28.

Carrillo, Jorge. 2018. "Manufactura dinamica en México y possibilidades de desarrollo regional:sectores automotriz y aeroespacial." In Cadenas Globales de Valor, edited by Enrique Dussel-Peters, 89-110. Mexico: UNAM. Facultad de Economía.

Castellanos Elías, Julio. 2016. "Industria Automotriz y TLCAN: Las Empresas Estadounidenses." Ola Financiera 9 (25): 128-63.

Castellanos, Julio, Lourdes Alvarez, and Martín G., María Antonieta; González Ma. Luisa. 2010. "Performance and Perspective of the Automotive Industry in Mexico after the 2009 Economic Crisis.” Gerpisa colloquium, Berlin. http://gerpisa.org/node/783.

Contreras, Oscar F., Jorge Carrillo, and Jorge Alonso. 2012. "Local Entrepreneurship within Global Value Chains: A Case Study in the Mexican Automotive Industry." World Development 40 (5): 1013-23.

Covarrubias, Alex, and Sigfrido M Ramírez Perez. 2020. "Wrapping Up: The New Geographies and Frontiers of the AI Have Arrived. Who Is Taking the Lead?" In New Frontiers of the Automobile Industry, edited by Alex Covarrubias and Sigfrido M Ramírez Perez, 455-94. Palgrave, McMillan.

Dussel Peters, Enrique, and Kevin P. Gallagher. 2013. "NAFTA's Uninvited Guest: China and the Disintegration of North American Trade." https://repositorio.cepal.org/handle/11362/37000.

Harrison, Bennett. 1997. Lean and Mean: The Changing Landscape of Corporate Power in the Age of Flexibility. Guilford Press.

Helper, Susan R, and Mari Sako. 1995. "Supplier Relations in Japan and the United States: Are They Converging?" MIT Sloan Management Review 36 (3): 77.

INA - Industria Nacional de Autopartes. 2019. "Presentation: Strategic Program of the Automotive: Vision 2024." 
Klier, Thomas, H., and James Rubenstein M. 2013. "Restructuring of the U.S. Auto Industry in the 2008-2009 Recession." Economic Development Quarterly 27 (2): 144-59. https://doi.org/10.1177/0891242413481243.

Klier, Thomas H., and James M Rubenstein. 2017. "Mexico's Growing Role in the Auto Industry Under NAFTA: Who Makes What and What Goes Where." Economic Perspectives. https://www.chicagofed.org/publications/economic-perspectives/2017/6.

Klier, Thomas, H., and James Rubenstein M. 2017. "Mexico's Growing Role in the Auto Industry Under NAFTA: Who Makes What and What Goes Where." Economic Perspectives. https://www.chicagofed.org/publications/economic-perspectives/2017/6.

Klier, Thomas, and James Rubenstein. 2020. "Overview of the U.S. Automobile Industry." In New Frontiers of the Automobile Industry: Exploring Geographies, Technology, and Institutional Challenges, edited by Alex Covarrubias V. and Sigfrido M. Ramírez Perez, 41-66. Palgrave Studies of Internationalization in Emerging Markets. Cham: Springer International Publishing. https://doi.org/10.1007/978-3-030-18881-8_2.

Mordue, Greig, and Brendan Sweeney. 2020. "Neither Core nor Periphery: The Search for Competitive Advantage in the Automotive Semi-Periphery." Growth and Change 51 (1): 34-57. https://doi.org/10.1111/grow.12354.

Norton, Roger D. 1986. "Industrial Policy and American Renewal." Journal of Economic Literature 24 (1): 1-40.

Paba, Sergio. 2021. The Chinese Automotive Industry at a Turning Point. An Overview. Convegno "L'industria Dell'auto e La Cina Nell'era Dell'auto Elettrica e Della Mobilità Sostenibile", 2 Luglio 2021, Modena, Dipartimento Di Economia Marco Biagi. https://www.youtube.com/watch?v=G8eINDPPUNE.

Pavlínek, Petr. 2018. "Global Production Networks, Foreign Direct Investment, and Supplier Linkages in the Integrated Peripheries of the Automotive Industry." Economic Geography 94 (2): 141-65. https://doi.org/10.1080/00130095.2017.1393313.

Romero, José Antonio, and Julen Berasaluce. 2018. Corea y México. Dos Estrategias de Crecimiento Con Resultados Dispares. El Colegio de Mexico AC.

Ros Bosch, Jaime. 2013. Algunas Tesis Equivocadas Sobre El Estancamiento Económico de México. Colegio de Mexico. https://www.jstor.org/stable/j.ctt14jxqmz.

Russo, Margherita, Fabrizio Alboni, Jorge Carreto Sanginés, Emanuele Murgolo, and Annamaria Simonazzi. 2021. "Who Produces What and Where. Companies and Countries in Vehicle Production, 1999-2017." Institute for New Economic Thinking Working Paper Series.

Russo, Margherita, Fabrizio Alboni, Jorge Carreto-Sangines, Emanuele Murgolo, and Anna Simonazzi. 2021. "Complex Network Analysis of the Dynamic of Changes in the Electric Vehicle Agent and Artifact Space." Institute for New Economic Thinking Working Paper Series. 
Russo, Margherita, Fabrizio Alboni, Manlio De Domenico, Jorge Carreto-Sangines, Giuseppe Mangioni, Simone Righi, and Annamaria Simonazzi. 2021. "Mapping Specialisations in the Automotive International Trade: A Multilayer Network Analysis." Institute for New Economic Thinking Working Paper Series.

Secrest, Fred G. 1981. "The American Automobile Industry and the Japanese Challenge. The Japanese Automotive Industry: Model and Challenge for the Future?" In The Japanese Automotive Industry, edited by Robert E. Cole, 41-50. Model and Challenge for the Future? University of Michigan Press. https://www.jstor.org/stable/10.3998/mpub.18647.10.

Schott, Jeffrey J. 2021. "Can Mexico help bring supply chains back to North America? September 21 https://www.piie.com/

Simonazzi, Annamaria. 1984. Governi, Banchieri e Mercanti. La Concorrenza Fra $i$ Paesi Industrializzati Nei Mercati Dei Paesi in via Di Sviluppo - FrancoAngeli. FrancoAngeli. https://www.francoangeli.it/Ricerca/scheda_Libro.aspx?codiceISBN=9788820441395.

Simonazzi, Annamaria, Jorge Carreto-Sangines, and Margherita Russo. 2020. "The Future of the Automotive Industry: Dangerous Challenges or New Life for a Saturated Market?" Institute for New Economic Thinking Working Paper Series 141.

$\mathrm{https}$ //www.ineteconomics.org/research/research-papers/the-future-of-the-automotive-industrydangerous-challenges-or-new-life-for-a-saturated-market.

Smitka, Mike, and Peter Warrian. 2016. A Profile of the Global Auto Industry: Innovation and Dynamics. Business Expert Press.

Tagliabue, John. 1995. "For Japan Auto Makers, It's Tougher in Europe." The New York Times, June 28, 1995, sec. Business. https:/www.nytimes.com/1995/06/28/business/for-japan-automakers-it-s-tougher-in-europe.html.

U.S. Congress, Office of Technology Assessment. 1992. "US-Mexico Trade: Pulling Together Or Pulling Apart?,.” ITE-545. Washington, DC: U.S. Government Printing Office.

USITC, and Mihir Torsekar. 2019. "U.S.-Mexico-Canada Trade Agreement: Likely Impact on the U.S. Economy and on Specific Industry Sectors.” USITC. www.usitc.gov.

Volkswagen de México. 2014. "Volkswagen de México. 50 Años Dejando Huella. 1964-2014. Mexico: Comunicación Corporativa."

Womack, James P, Daniel T Jones, and Daniel Roos. 1990. The Machine That Changed the World. New York: Free Press.

Womack, James P., Daniel T. Jones, and Daniel Roos. 2007. The Machine That Changed the World: The Story of Lean Production. Simon and Schuster. 